\title{
The Editors*
}

\section{Coda: Ten Questions for a Diplomat}

DOI 10.1515/ngs-2017-0019

Abstract: Thomas Niles served as a United States foreign service officer from 1962 to 1998. His service included three terms as ambassador: to Canada, the European Community, and Greece. He reflects here on the continuities in the diplomatic profession, and, in particular, on embassies, during a period of notable historic change. While many of the protocols and responsibilities of embassies remained more or less the same as they had been for over a century, there were hints that those, too, were about to change in unforeseen ways, even calling into question the central role of embassies as representing and serving the nation-state, as the other articles in this issue discuss. Nevertheless, to this ambassador, at least, even dramatic changes in technology, politics, and culture rarely happen all at once; and the institutions and the people adapting to them may be more cautious or durable than they sometimes appear in retrospect.

Keywords: diplomacy, Post-Cold War, embassies, ambassadors

NGS: How much of a role in diplomacy did the embassy itself (chancery \& residence) play during your time as an ambassador?

TN: In each of my three ambassadorial assignments, I saw my role as that of the captain of a team. My effort was aimed at instilling in each member of the embassy staff a sense that we were all in this together and that our success depended upon the contribution of each member of the team. I tried to involve all staff members in my work, and I also tried to make clear my interest in the work that all parts of the embassy were doing. I could not have functioned with the support of my colleagues, and the idea of an ambassador somehow performing his or her mission without the support of the rest of the embassy makes no sense to me. As regards the official residence, it, too, was in my view part of the overall mission. I regarded entertainment at the residence as work, not socializing. I found that often more could be accomplished over good food and drink at lunch or dinner than in formal official meetings, and I used the residences for that purpose. The major advantage of an informal discussion over a meal, and the quality of the cuisine and drinks was important, was that both sides could throw out ideas that they would not want to

*Corresponding author: The Editors, E-mail: ngseditors@gmail.com 
advance in a formal, office meeting. The absence of note takers, which I insisted upon at such occasions, was also important. I believe that these discussions often resulted in progress toward the resolution of the issues under consideration. And my colleagues and I prepared for these occasions just as we prepared for formal meetings, gaming them out beforehand. My wife found it a bit tedious at times, but she understood the purpose.

NGS: Describe the ambassadorial role as you recall it. Would you say it was traditional or somehow different from what most people know embassies to do and to be?

TN: My time as an ambassador began in 1985 and ended in 1997. This was a revolutionary period in terms of the geopolitical environment in which US national security policy was made and implemented, but the basic techniques did not change fundamentally. I must confess that the idea of changing our fundamental approaches never occurred to me. I felt that I was part of a tradition that went back to the seventeenth century, and I was proud to be a part of it. I suppose the old adage "never change a winning game" would apply. What we had been doing and the way in which we had been doing it had worked, so why change it. Since then, the coming of the Internet has brought fundamental changes into literally all areas of human activity, and while I have no direct, personal familiarity with the ways the practices of diplomacy have changed, I feel sure that major changes have occurred. During my last assignment as ambassador to Greece (1993-1997), for the first time as an ambassador I had a messaging terminal on my desk. It was part of a world-wide, unclassified messaging system set up by the State Department employing equipment and technology supplied by a company that no longer exists, Wang Laboratories. But this relatively primitive system gave us vastly enhanced communications with the State Department and other US diplomatic posts around the world. Essentially, these messages simply supplemented the more traditional messages. Keep in mind that this system was only for unclassified message traffic. It probably made us more efficient, and it definitely enhanced the ability of "Washington" to control what we did.

NGS: How many members of the embassy staff could be classified as "diplomats?" Was this also seen as normal?

TN: As far as I was concerned, every member of my staff was a "diplomat," contributing in one way or another to the fulfillment of our shared mission, [although i]t varied. In Ottawa, because of the unique intelligence relationship between the CIA and its Canadian counterparts, I had one CIA officer on my staff, and he was there strictly for liaison purposes. 
NGS: How, in your own experience and by what you know from colleagues, have embassies changed, both during your time as ambassador and since?

TN: My time as ambassador was from 1985 to 1997. Each post - Canada, EC, Greece - was different, but this had mainly if not exclusively to do with the differences in the substantive issues in the relationships. I feel sure that the coming of the internet has had a big impact. When I retired, I had no inkling of what probably lay ahead. In terms of organization and structure, the missions that I headed in Ottawa and Athens were similar except that there was a large CIA station in Athens but none in Ottawa. The mission to the European Community was different primarily in that it did not have its own administrative section and several of the sections of other, more "traditional" embassies were also lacking. Even if I go back to my first foreign post - Belgrade in 1963 - I cannot come up with major differences between that embassy and embassy Athens in 1997. [However, s] ecurity costs began to be a major factor in embassy budgets after the 1982 attack on our embassy in Beirut and the issuance of the Inman Report. ${ }^{1}$ By the time I got to Greece (1993), security was one of my major preoccupations, partly because we had to deal with the lethal Greek terrorist organization, $\mathrm{N}-17$.

NGS: Do you think most countries still need embassies? What purpose do they serve? How do you imagine that will change in the future?

TN: Countries still need to manage their relations on a day-to-day basis, and while advances in telecommunications may make this easier, the need for embassies continues in my view. Governments need someone to explain developments and advocate policies to other governments, and having people permanently on the scene in other capitals makes sense. I believe that without a permanent embassy, ambassador and staff you would lose the benefits of continuity in working the issues. My crystal ball is cloudy as far as the future is concerned.

NGS: If you could have redesigned any of your embassies-meaning their role, but not necessarily the physical space-how would you have done it? What role or purpose might they have better served?

TN: All of the missions I headed could have been more effective with more people. The State Department budget was under constant stress and strain, and the Congress was always making cuts that forced retrenchments which really were not cost effective.

1 Report of the Secretary of State's Advisory Panel on Overseas Security (Washington, D.C.,: U.S. Department of State, 1985). [Eds.] 
NGS: We are told that today we are living in a global era, yet nearly all embassies fly national flags and are considered to be sovereign islands on foreign soil. Does this reinforce the image \& power of the nation-state? Or does it seem more \& more anomalous?

TN: National embassies flying the national flag make sense so long as independent countries exist. I think this reflects the reality of international life. If the EU were to become a real federation, I assume the national embassies would disappear, as I assume embassies of German states such as Bavaria disappeared in 1871. When I was in Brussels as Ambassador to the European Community, now European Union, the EC, or EU, diplomatic service was emerging. This made sense because the European Commission represented the member states in some important areas of international relations, beginning with international trade. So, in many national capitals, there were EC, now EU, representations. And I would assume that since then the EU diplomatic service has become more active and prominent internationally. A "common foreign and security policy" deserves a common diplomatic service, and that has now emerged.

NGS: The US has a long-standing tradition of appointing non-professionals to be ambassadors: celebrities, political funders, etc. Other countries have begun to adopt the practice. What impact does this have on the role of an embassy? Does it detract from its central diplomatic function, or perhaps give it even greater prominence?

TN: When I was in the foreign service, our pernicious practice of appointing political bagmen, or bagwomen, as ambassadors was unique to the United States. If other countries have now begun to follow our bad example, too bad for them. In most cases, having a bagmen or bagwoman at the head of an embassy reduces its effectiveness and can, in the worst case, make the embassy, and by extension, our country look ridiculous. If this becomes an ever more pervasive practice, it will undermine and perhaps ultimately destroy the professional diplomatic service. The question is whether anyone in a position of authority, either executive or legislative, would care were this to happen. The current administration's budget proposal does not suggest any particular concern for diplomacy or the diplomatic service, per se. It will be interesting to see whether the Congress shares that attitude.

NGS: Do you think that some positions among the embassy staff have become more important over the years, and/or some positions declined in importance?

TN: I did not detect any such changes. The need for specialized attachés depends upon the situation in the country of assignment. To illustrate the 
point, using an admittedly extreme case, it makes no sense to have a Treasury attaché in Prague while one is certainly needed in London. As long as embassies issue visas and have the responsibility of looking after the interests of our citizens who travel/live abroad, consular officers will be needed.

NGS: In an era of ever-increasing global connections, what do embassies continue to represent?

TN: I always thought that the embassy represented the country, and I see no reason why that should change. There is no question that the field has become more crowded with the emergence of multinational corporations and other NGOs. But I did not see the NGOs as competitors or alternatives to the role I was playing. However, their emergence added the need to try to coordinate the activities of the various NGOs with those of the embassy to the extent they overlapped in an effort to ensure that, to the extent possible, we were all working toward compatible objectives or at least were not undercutting each other. 